\title{
High inflation and returns on residential real estate: evidence from Turkey
}

\section{Zeynep Onder}

To cite this article: Zeynep Onder (2000) High inflation and returns on residential real estate: evidence from Turkey, Applied Economics, 32:7, 917-931, DOI: 10.1080/000368400322255

To link to this article: http://dx.doi.org/10.1080/000368400322255

$$
\text { 曲 Published online: } 04 \text { Oct } 2010 .
$$

\section{Submit your article to this journal $\square$}

Џlll Article views: 106

Q View related articles ¿

Citing articles: 9 View citing articles ए 


\title{
High inflation and returns on residential real estate: evidence from Turkey*
}

\author{
ZEYNEP ÖNDER
}

Bilkent University, Faculty of Business Administration, Bilkent, Ankara 06533, Turkey

E-mail: zonder@bilkent.edu.tr

This study examines the hedging behaviour of real estate investment in a high inflationary environment. The hypothesis that the real estate investment hedges both expected and unexpected inflation is tested. The returns of investment on residential apartments in several neighbourhoods in the capital of Turkey are used in the analysis. Expected inflation is measured by three proxies. It is found that in a high inflationary environment, real estate investment does not provide hedge against inflation. A reverse causality between returns on real estate and changes in expected inflation is not observed. However, a relationship between real returns and changes in inflationary expectations seem to be different in relatively low and relatively high income neighbourhoods.

\section{INTR ODUCTION}

Several studies have examined whether assets provide effective hedges against inflation. The results of these studies have suggested that assets are different in terms of their hedging behaviour against expected and unexpected inflation. Common stocks act as a perverse hedge against both expected and unexpected inflation in most of the developed markets examined (for example, Bodie, 1976; Nelson, 1976; Fama and Schwert, 1977; Firth, 1979; Fama and Gibbons, 1982; Gultekin, 1983). Although the returns on common stocks are negatively correlated with expected and unexpected inflation, it is found that real estate investment is a good hedge against expected and unexpected inflation. For example, Gyourko and Linneman (1988) find a positive association between appreciation in residential and nonresidential real estate and inflation. Similarly, using the percentage change in the home purchase price component of the CPI as the return on privately held residential real estate, Fama and Schwert (1977) conclude that real estate can hedge expected and unexpected inflation.
Results are different for the hedging behaviour of real estate investments depending on the proxy used for measuring expected inflation. For example, forecasting inflation with AR MA model, Gyourko and Linneman (1988) find a strong negative correlation between return on real estate investment trusts (REITs) and unexpected inflation. Similarly, Gartzlaff (1994) finds that estimates of unexpected inflation using the adoptive expectations model and the rational expectations model are positively correlated with excess returns to housing. Park et al. (1990) use two proxy measures for expected inflation. They find that REITs behave as perverse inflation hedges when they measure anticipated inflation with the return on Treasury bills. On the other hand, using Livingston's inflation expectations, REITs seem to act as partial hedges against expected inflation but not for unanticipated inflation. Expanding the analysis to the international property trusts, Liu et al. (1997) find that the degree of perverse hedging behaviour of trusts is different among countries in their sample.

The hedging behaviour of real estate returns can be explained with the following relationship. An increase in inflation rate reduces the effective cost of home ownership

* An earlier version of this paper was presented at the 1998 Joint International Conference of the American Real Estate and Urban Economics Association and the European Real Estate Society meeting in Maastricht, the Netherlands. 
because of the decline in the relative cost of mortgage, hence, the tax subsidy to owner occupation is increased. The decline in the relative cost of home ownership will increase the demand for owner occupation, as a result, house prices will increase. Several researchers, for example, Summers (1981), Poterba (1984), Goodwin (1986) and Manchester (1987), have explained the boom in house prices in the US during the 1970s this way.

These results suggest that housing and mortgage markets and taxation might explain the expected and unexpected inflation hedging behaviour of real estate returns. Almost all of the countries examined has not experienced high inflation. There is a question of whether hedging behaviour of real estate can be extended to a high or hyper-inflationary economy. The Turkish market provides a good opportunity to test the hedging behaviour of real estate under high inflation. The inflation rate in Turkey is very high relative to all other countries examined in the literature. The average annual inflation rate has been more than $50 \%$ since 1986 .

This is the first study that examines the hedging behaviour of real estate investment in a high inflationary environment. The real estate and mortgage markets in Turkey have different characteristics compared to the developed markets that are examined extensively. In addition to high inflationary economy, there is not a good mortgage market in Turkey. The downpayment requirement for purchasing a house is very high, reaching to $70 \%$ of the house value in some cases. Additionally, the longest term on home mortgage loans is five years. Hence, we cannot argue that the existence of inflation reduces the cost of home ownership. Tax regulations are also different. For example, mortgage payments are not tax deductible. In case of the sale of housing units, both buyer and seller have to pay equal amount of tax.

This study examines the relationship between inflation and returns on residential real estate investment in the capital of Turkey, Ankara. The asking prices of apartments on sale in several neighbourhoods in Ankara are collected for the analysis. The quarterly inflation rate and returns on real estate are calculated for the period between the first quarter of 1977 and the last quarter of 1996. Unlike the studies that examined developed markets, it is hypothesized that returns on real estate do not significantly hedge against expected and unexpected inflation. In addition, Fisherian Direct Causality and Reverse Causality hypotheses are tested using returns on residential real estate investment in Ankara. For comparison, the models are also estimated for the returns on stocks traded in the Istanbul Stock Exchange (ISE). The results do not indicate that real estate investment in Ankara is a good hedging instrument against expected and unexpected inflation.

The paper is organized as follows. The next section gives information about the real estate and mortgage markets in Turkey. The methodology and data used in the analysis are presented in the third section. The fourth section presents the results of the analysis. The fifth section concludes the paper.

\section{BA CKGR OUND: INFLATION, REAL ESTATE AND MORTGAGE MARKETS IN TUR KEY}

In this section, some information about inflation, housing supply and mortgage market in Ankara are given in order to understand the relationship between inflation and returns on real estate in Turkey.

\section{Inflation}

Turkey has experienced high inflation since 1977. A sudden increase in oil prices in the world in 1977 had an impact not only on the developed economies but also developing economies like Turkey. Since Turkey is an oil importing country, the increase in oil prices increased the demand for foreign currencies, and the financing of large current account deficits with external borrowing led to foreign exchange shortage. A series of devaluation of Turkish Lira against foreign currencies and the adjustment process with current account deficit resulted in a sharp increase in inflation for the period between 1977 and 1980.

The stabilization and liberalization policies in January 1980 settled down the economy. According to these decisions, first, interest rates were allowed to float. Then, they were increased above the inflation rate. Even though the real interest rates were negative until 1980, after these decisions they became positive. An increase in interest rates attracted many people to invest in money market instruments and resulted in the decline in the demand for housing, which is considered as an alternative way of investment. Individuals started to sell their houses and invest in the money market instruments. It is found that the demand for housing decreased when the real interest rate on demand deposits was positive (Korum, 1982).

Large amount of domestic borrowing at high levels of interest rate led inflation rate to increase to $40 \%$ in 1984 . Then, it reached $50 \%$ during the second half of the 1980 s as the domestic debt finance had been the major source of financing (Özmen, 1998). Political instability derailed the success of some disinflation programmes and inflation rate continued to increase. In 1994, another jump in inflation occurred because of foreign exchange crises and Turkey had experienced three digit inflation rates. Figure 1 shows the annual inflation rate over the period analysed in this study. 


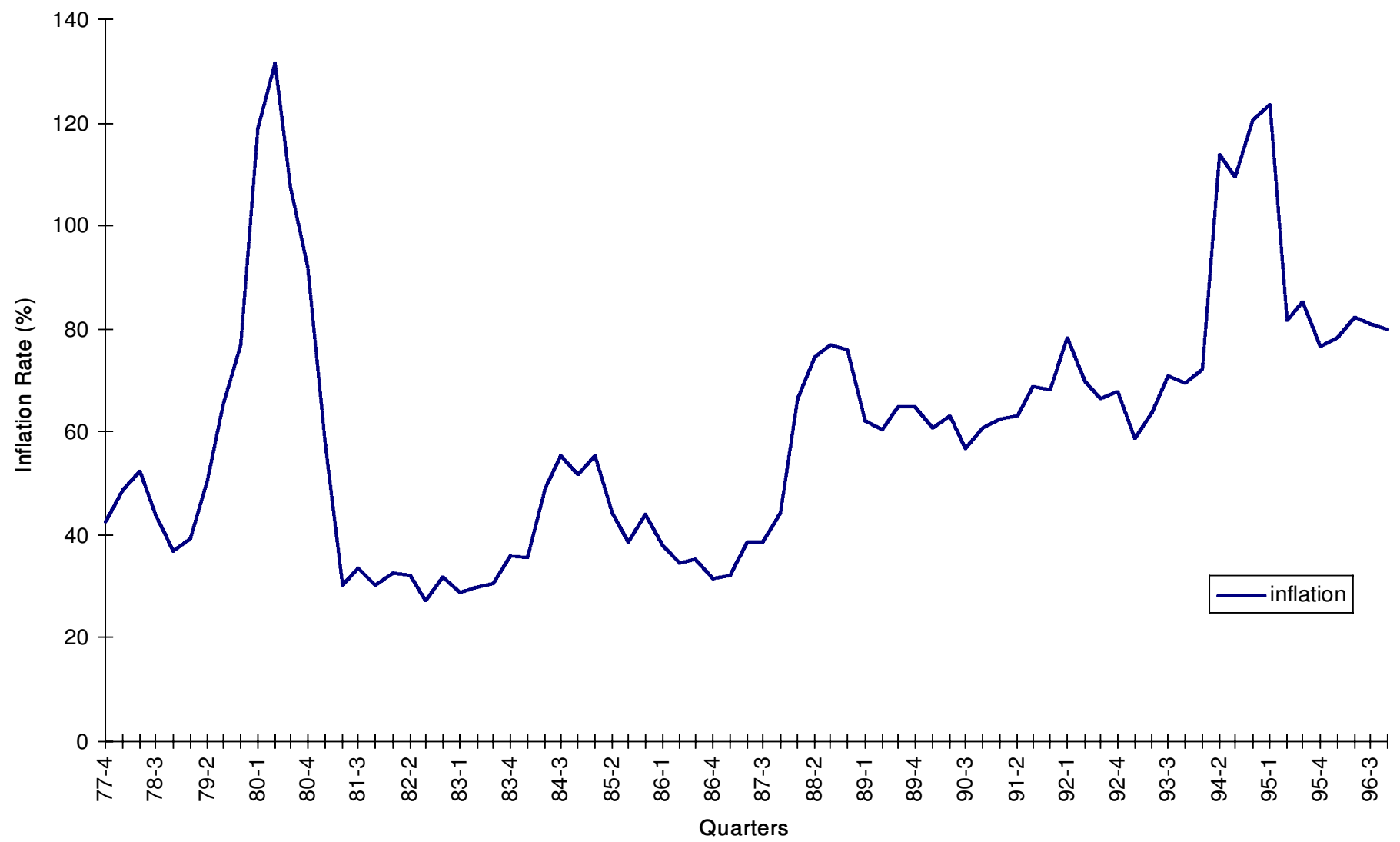

Fig. 1. Annual inflation rate for the period 1977-1996

\section{Mortgage market in Turkey}

The Turkish mortgage market is not well developed. Private lenders, mainly banks, started to give mortgages only in the late 1980s as part of their consumer loan programmes designed not specifically for home buying. They were short-term and fully amortizing loans with the maximum loan term between 1 to 5 years. The interest rate on loans has adjusted periodically. Several banks have different requirements for the mortgage origination. The maximum loan-to-value ratio has been changing between $50 \%$ and $70 \%$. Some banks also have limits on the loan amount that an individual can borrow.

In addition to private lenders, the loans from a governmental organization, Housing Development Administration, are available for individual home buyers. They are also originated by the private lenders that charge commission and servicing fee for loan originations. These loans have more favourable terms than loans provided directly by private lenders. Even though these loans had terms of up to 15 years, fully amortized with fixed interest rate before 1989, interest rates have started to be adjusted using CPI and terms have reduced after 1989. These loans are also available to home builders, especially to cooperatives that are responsible for the development of many housing projects in Turkey.

The private lenders offer construction loans to the home builders as well. These loans are used by yapsatci, a small scale home builder. ${ }^{1}$ Most of the apartments analysed in this study were constructed by this type of builders. Lenders have different requirements for them. For example, downpayment requirement has been changing between $20 \%$ and $50 \%{ }^{2}$

\section{Real estate market in Ankara}

Ankara is one of the most developing cities in Turkey. The population has increased with the migration of households from rural areas and other cities to Ankara. According to 1980 and 1990 Censuses, the population in one central county (or township) in Ankara increased by $52 \%$. The increase in population should increase the demand for housing. However, since the mortgage

\footnotetext{
${ }^{1}$ Yapsatci is in English translation, build and sell.

2 These information are taken from the interviews with the major banks providing mortgages to individuals and home builders, made by the Fannie Mae (1992).
} 
market is not well developed and buying a house requires large amount of saving, the demand for owner-occupied housing has not increased as much as the increase in population. The requirements of lenders for permanent income and a sufficient amount of money for downpayment led to the development of slum houses at the outskirts of the city.

In Ankara, there are several neighbourhoods. Some neighbourhoods are located in the central part of the city and some are located at the outskirts. As the population in Ankara increased, the densities increased. ${ }^{3}$ Since the land is limited in the central part, the increase in housing supply occurs with the rebuilding of higher story buildings or building new apartments on the limited land.

In the central part of the city, the densities increased by allowing higher floor buildings in already built-up areas. In these areas, most of the development of housing units is performed by yapsatci. They construct on single spots. They can either buy the land and construct apartments or they agree with the land owner to give some apartments in return for land.

An increase in demand for housing led the government to increase the supply of land for housing. This is achieved with two sources (Baharoglu et al., 1997). The first one is the development of the new urban land at the outskirts of the city. The second one is the legalization of the unauthorized land where slum houses are located. This resulted in the increase in housing supply in neighbourhoods located not only at the central area but also in areas close to the outskirts of the city.

The increase in the housing supply has been high on the outskirts of the city because the new land area has been allowed for construction. This resulted in the construction of new suburban neighbourhoods that are 10-20 kilometres from the central city. The construction on the outskirts of the city is done usually by cooperatives and the state organization, called Housing Development Administration and the Real Estate Bank which provide some financing benefits to the cooperatives and individuals buying apartments in these buildings. So, financing alternatives are different for these groups. In this study, the selected neighbourhoods are located in the central part of the city.

The apartment prices in several neighbourhoods in Ankara are shown in Table 1. The variation in values among neighbourhoods is not only related with the cost of construction because of differences in land prices. The availability of shopping centres, the existence of cooperative buildings, hotels, embassies and the quality of housing construction also influence variation in prices. The vari- ation in house values in Ankara is also documented by Turel (1981).

\section{METHODOLOGY AND DATA}

\section{Models}

Three models are used to examine the relationship between inflation and returns on residential real estate in Ankara. The first one is Fama-Schwert (1977) model which is based on the Fisher's well-known argument that the nominal interest rate can be expressed as the sum of the expected inflation and the expected real rate of return. Applying this argument to all assets, the expected nominal return on assets can be expressed as the sum of the expected inflation and the expected real return. In analysing the hedging behaviour of assets, the model developed by Fama and Schwert (1977) is extensively used since it is possible to identify the relationship between return on assets and both expected and unanticipated components of inflation. Their model is expressed as follows:

$$
\tilde{R}_{i, t}=\alpha+\beta E\left(\tilde{I}_{t}\right)+\gamma\left[\tilde{I}_{t}-E\left(\tilde{I}_{t}\right)\right]+\varepsilon_{i t}
$$

where $\tilde{R}_{i, t}$ represents the return on the asset $i$ at time $t$. $\tilde{I}_{t}$ and $E\left(\tilde{I}_{t}\right)$ correspond to the actual and expected inflation rates, respectively. If an asset provides a complete hedge against expected and unexpected inflation, both $\beta$ and $\gamma$ should be 1 .

According to Fisher, the expected real return is determined solely by real factors, such as productivity of capital, investors' time preferences, tastes for risk. Hence, the expected real return and the expected inflation rate are unrelated. This hypothesis, which is called Fisherian Direct Causality hypothesis, is tested using Solnik (1983) model:

$$
\tilde{r}_{i, t}=\alpha+\beta_{1} E\left(\tilde{I}_{t}\right)+\beta_{2}\left[E\left(\tilde{I}_{t+1}\right)-E\left(\tilde{I}_{t}\right)\right]+e_{i t}
$$

where $\tilde{r}_{i, t}$ is the ex post real rate of return on asset $\left(\tilde{r}_{i, t}=\tilde{R}_{i, t}-\tilde{I}_{t}\right)$. Under the null hypothesis, both coefficients are expected to be zero since real returns are independent of any expected inflation level or expected changes in inflation.

As a third model, Geske and Roll's (1983) hypothesis is tested. Unlike Fama and Schwert (1977) and Solnik (1983), they conjecture that fluctuations in return on assets cause changes in inflationary expectations. Their reverse causality model is tested using the following model:

$$
E\left(\tilde{I}_{t+1}\right)-E\left(\tilde{I}_{t}\right)=\alpha+\delta_{1} E\left(\tilde{I}_{t}\right)+\delta_{2} \tilde{R}_{i, t}+e_{t}
$$

\footnotetext{
${ }^{3}$ For example, according to the 1980 Census, there were 2023, 1576 and 663 people living in one square kilometre area in Cankaya, Kecioren and Yeni Mahalle counties in Ankara, respectively. These numbers increased to 2326, 2684 and 834 according to the 1990 Census.
} 
Table 1. Descriptive statistics of the median apartment values in several neighbourhoods in Ankara based on December 1996 prices (in million T.L. and US\$)

Median value of apartments (million T.L.)
Median value of apartment with

100 square metre space (million T.L.)

\begin{tabular}{|c|c|c|c|c|c|c|c|c|}
\hline \multirow{2}{*}{ Neighbourhood } & & & & & \\
\hline & Mean & Std dev & Minimum & Maximum & Mean & Std dev & Minimum & Maximum \\
\hline Anittepe/Maltepe & 3797 & 1291 & 1972 & 9112 & 3641 & 916 & 2198 & 6197 \\
\hline Aydinlikevler & 2282 & 785 & 1038 & 4203 & 2418 & 660 & 1177 & 3746 \\
\hline Ayranci & 4415 & 1323 & 1293 & 7850 & 3999 & 1108 & 1659 & 8116 \\
\hline Bahceli/Emek & 3900 & 1289 & 1432 & 7156 & 3756 & 1029 & 1638 & 7584 \\
\hline Cankaya & 7637 & 2213 & 3023 & 13796 & 5738 & 1293 & 2848 & 8737 \\
\hline Cebeci/Dikimevi & 2340 & 721 & 1046 & 5140 & 2628 & 771 & 1230 & 5122 \\
\hline Demetevler/Y.mahalle & 1799 & 484 & 770 & 3268 & 1783 & 764 & 786 & 5241 \\
\hline Dikmen & 2984 & 813 & 1276 & 5955 & 3025 & 851 & 1647 & 6989 \\
\hline Etlik & 2427 & 953 & 1117 & 6970 & 2455 & 880 & 1083 & 4469 \\
\hline G.O.P. & 7658 & 3013 & 2299 & 17549 & 5856 & 1789 & 2296 & 10043 \\
\hline Kecioren & 2064 & 537 & 895 & 3300 & 2193 & 654 & 657 & 3537 \\
\hline Kavaklidere & 5951 & 2291 & 1368 & 14318 & 5125 & 1530 & 1259 & 8678 \\
\hline \multirow[t]{2}{*}{ Esat } & 3385 & 980 & 1623 & 5702 & 3446 & 985 & 1309 & 7887 \\
\hline & \multicolumn{4}{|c|}{$\begin{array}{l}\text { Median value of apartments } \\
\text { (US \$) }\end{array}$} & \multicolumn{4}{|c|}{$\begin{array}{l}\text { Median value of apartment with } \\
100 \text { square meter space (US \$) }\end{array}$} \\
\hline Anittepe/Maltepe & 34995 & 11899 & 18175 & 83982 & 33558 & 8442 & 20258 & 57115 \\
\hline Aydinlikevler & 21032 & 7235 & 9567 & 38737 & 22286 & 6083 & 10848 & 34525 \\
\hline Ayranci & 40691 & 12194 & 11917 & 72350 & 36857 & 10212 & 15290 & 74802 \\
\hline Bahceli/Emek & 35945 & 11880 & 13198 & 65954 & 34618 & 9484 & 15097 & 69899 \\
\hline Cankaya & 70387 & 20396 & 27862 & 127152 & 52885 & 11917 & 26249 & 80525 \\
\hline Cebeci/Dikimevi & 21567 & 6645 & 9641 & 47373 & 24221 & 7106 & 11336 & 47207 \\
\hline Demetevler/Y.mahalle & 16581 & 4461 & 7097 & 30120 & 16433 & 7041 & 7244 & 48304 \\
\hline Dikmen & 27502 & 7493 & 11760 & 54885 & 27880 & 7843 & 15180 & 64415 \\
\hline Etlik & 22369 & 8783 & 10295 & 64240 & 22627 & 8111 & 9982 & 41189 \\
\hline G.O.P. & 70581 & 27770 & 21189 & 161742 & 53972 & 16488 & 21161 & 92562 \\
\hline Kecioren & 19023 & 4949 & 8249 & 30415 & 20212 & 6028 & 6055 & 32599 \\
\hline Kavaklidere & 54848 & 21115 & 12608 & 131963 & 47235 & 14101 & 11604 & 79982 \\
\hline Esat & 31198 & 9032 & 14959 & 52553 & 31760 & 9078 & 12065 & 72691 \\
\hline
\end{tabular}

Under the null hypothesis, both coefficients are expected to be less than zero. The coefficient on $E\left(\tilde{I}_{t}\right)$ represents the speed of adjustment for expected inflation. The coefficient on $\tilde{R}_{i, t}$ shows the impact of the asset returns on changes in the expected change in inflation.

All these models are tested for returns on residential real estate in several neighbourhoods in Ankara using three different inflation expectations. Ordinary least squares procedure is used in the estimations. When autocorrelation or heteroscedasticity is detected, standard errors are estimated using Newly-West correction procedure. In order to make comparison, all the models are also estimated for the return on the ISE stock index.

\section{Expected inflation}

Three proxies are used to measure expected inflation. As a first proxy, using quarterly inflation rates over the analysis period, inflation rate is forecasted with the AR MA model.
The ARMA model is selected based on Akaike and Schwarz Information criteria. The model is presented in Table 2. The other expected inflation measures are applied only for the period between the first quarter of 1986 and the last quarter of 1996 because the T-bill market has been operating since 1986. The lagged returns on 3-month Tbills are taken as a second measure of the expected inflation rate. The third proxy is the one offered by Fama and Gibbons (1982). The expected inflation rate is estimated using the yield on 3-month T-bills. Most of the previous research used these measures as an approximation for the expected inflation rate.

The effectiveness of these three proxies is measured using a regression model and presented in Table 2. The expected inflation rate with ARMA model has the highest $R^{2}$. The estimated constant is not significantly different from zero, except for the second proxy, the lagged return on 3-month T-bill.

\footnotetext{
${ }^{4}$ The State Institute of Statistics has calculated the CPI for Ankara since 1987. The estimations are also obtained by using this price index for the period after 1987. The results were similar. They are not reported here but available from the author upon request.
} 
Table 2. Regression estimates for the evaluation of the expected inflation rates: Model: $I_{t}=\alpha+\beta E\left(I_{i t}\right)+e_{t}$

\begin{tabular}{lccc}
\hline & $\begin{array}{l}\text { Parameter } \\
\text { estimate }\end{array}$ & $t$-statistic & $R$-square \\
\hline$E\left(I_{1 t}\right)$ & & & \\
$\alpha$ & -0.007 & -0.308 & 0.302 \\
$\beta$ & 1.052 & 5.618 & \\
$E\left(I_{2 t}\right)$ & & & \\
$\alpha$ & 0.076 & 3.185 & 0.132 \\
$\beta$ & 0.354 & 2.463 & \\
$E\left(I_{3 t}\right)$ & & & \\
$\alpha$ & 0.000 & 0.000 & 0.156 \\
$\beta$ & 1.000 & 2.757 & \\
\hline
\end{tabular}

Note.

Expected inflation estimations:

$E\left(I_{1 t}\right)$ is estimated using ARMA modelling. AR(1), MA(4), and SAR(4) are used in forecasting inflation rates. This model provided the highest Akaike and Schwarz information criteria.

Estimation results:

$$
\begin{aligned}
\left(E\left(I_{1 t}\right)=\right. & (0.925)+(0.308) \cdot\left(I_{t-1}\right)+(0.996) \cdot\left(I_{t-4}\right) \\
& \left.+(-0.960) \cdot\left(u_{t-4}\right)\right)
\end{aligned}
$$

\section{$R$-squared}

0.301

Akaike info criterion $\quad-5.997$

Schwarz criterion $\quad-5.874$

$F$-statistic $\quad 10.184$

$E\left(I_{2 t}\right)$ is the lagged return on 3 -month T-bill. $\left(E\left(I_{2 t}\right)=T-\right.$ Bill $\left._{t-1}\right)$.

$E\left(I_{3 t}\right)$ is estimated using the regression of inflation with the return on 3-month T-bill.

$$
\begin{aligned}
\left(E\left(I_{3 t}\right)=\right. & \left.(0.076)+(0.354) \cdot\left(T-\text { Bill }_{t-1}\right)\right) \\
(3.185) & (4.312)
\end{aligned}
$$

$t$-statistics are in parentheses.

In the analysis, CPI reported by the State Institute of Statistics is used in order to estimate the rate of inflation. ${ }^{4}$ The natural logarithm of the ratio of the CPI values at time $t$ and $t-1$ is calculated.

The quarterly analysis is employed. The time period covered in the study is between the first quarter of 1977 and the last quarter of 1996. Since both stock market and bond market have been operated since 1986, some analyses are done for the period after 1985 which corresponded to the high inflationary period.

\section{Measures of return on real estate}

A proxy that is widely used in the literature for measuring return on real estate is the appreciation rate in the house purchase price component of the CPI (for example, Fama and Schwert, 1977). Unfortunately, only rents, the prices of utilities and the maintenance costs are considered as housing expenses in the Turkish CPI calculation. Hence, it is not possible to use this component as a return on real estate investment. If this component of the CPI is used, income component but not the appreciation in the real estate values will be included in the real estate returns.

In the literature, the return on REITs is widely used as another alternative. They behave like hybrid assets between stocks and real estate. There are only four REITs traded in the Istanbul Stock Exchange (ISE), all of them were issued in 1997. Hence, there is not sufficient number of observations regarding returns on REITs to compare with expected inflation. In addition, the portfolio of these REITs consists of mainly nonresidential real estate, such as land and office buildings.

All these restrictions resulted in the collection of new data from daily newspapers. Daily newspapers have sections where individuals or real estate agencies can list houses or apartments for sale. They provide information about real estate, such as price, location, size, number of bedrooms, heating facilities, number of baths, age of housing unit, etc. The prices and some reported characteristics of the apartments listed in the daily newspapers at the end of each quarter are collected for the analysis. Unfortunately, these asking prices are not claimed to be actual transaction prices of apartments but since the appreciation rate is calculated, this bias will be consistent over all real estate values.

There is a dispersion in house values in Ankara. Therefore, the apartment appreciation rates in different neighbourhoods are analysed. Returns are calculated from two bases. The first one is the change in the median apartment value for sale in each neighbourhood at the end of each quarter. The second one is based on the change in median value of apartments with 100 square metre space. Log returns are used in the calculations.

The data on apartments for sale at the end of each quarter are collected for the thirteen neighbourhoods in Ankara: Aydinlikevler, Anittepe/Maltepe, Ayranci, Bahceli/Emek, Cankaya, Cebeci/Dikimevi, Demetevler/Yeni Mahalle, Dikmen. Etlik, Esat, G.O.P., Kavaklidere and Kecioren. There are differences in the characteristics of households residing in these neighbourhoods. Some neighbourhoods are preferred by relatively high-income households and some of them are preferred by relatively low-income households. In addition, some of them are located at the central part of the city and some of them are close to the outskirts of the city. Table 1 shows some descriptive statistics of the median apartment values and the median value

\footnotetext{
${ }^{5}$ Instead of using 13 neighbourhoods, another possibility is creating a housing index in Ankara using hedonic estimation. There are only limited numbers of housing units with detailed housing characteristics. The sample consists of 7057 units with value and location. The number of observations declines to 2785 with size. However, if we want to include any other characteristics, there are only 545 units left in the sample.
} 
Table 3. Means, standard deviations and autocorrelations of quarterly nominal rates of return

\begin{tabular}{|c|c|c|c|c|c|c|c|}
\hline & Mean & Std. dev. & $\rho_{1}$ & $\rho_{2}$ & $\rho_{3}$ & $\rho_{4}$ & Time period \\
\hline \multicolumn{8}{|l|}{ Returns on real estate } \\
\hline Aydinlikevler & 0.0898 & 0.3973 & -0.4600 & -0.1850 & -0.0130 & 0.0280 & 1980:3-1996:4 \\
\hline Anittepe/Maltepe & 0.1194 & 0.3947 & -0.5020 & -0.3050 & -0.1850 & 0.0160 & 1977: 1-1996:4 \\
\hline Ayranci & 0.1205 & 0.2905 & -0.5740 & -0.0900 & -0.2130 & -0.2350 & 1977: 1-1996:4 \\
\hline Bahceli/Emek & 0.1186 & 0.2889 & -0.3430 & -0.1080 & -0.3710 & -0.2240 & 1977: $1-1996: 4$ \\
\hline Cankaya & 0.1185 & 0.2963 & -0.3690 & -0.2810 & -0.0630 & -0.1950 & 1977: 1-1996:4 \\
\hline Cebeci/Dikimevi & 0.1256 & 0.3684 & -0.5060 & -0.1620 & -0.0270 & -0.2370 & 1977: 1-1996:4 \\
\hline Demetevler/Y.mahalle & 0.1271 & 0.3295 & -0.4690 & -0.2000 & -0.1230 & -0.1120 & 1980:3-1996:4 \\
\hline Dikmen & 0.1052 & 0.2560 & -0.4340 & -0.0810 & 0.0000 & 0.0400 & 1984:3-1996:4 \\
\hline Etlik & 0.1236 & 0.3695 & -0.3590 & -0.2280 & -0.3040 & -0.0270 & 1979:2-1996:4 \\
\hline Esat & 0.1251 & 0.3336 & -0.4390 & -0.0940 & 0.0340 & 0.1640 & 1977: 1-1996:4 \\
\hline G.O.P. & 0.1192 & 0.3489 & -0.3650 & -0.1640 & -0.2070 & -0.0540 & 1980:3-1996:4 \\
\hline Kavaklidere & 0.1128 & 0.5531 & -0.6310 & -0.3570 & -0.2430 & -0.1720 & 1977:1-1996:4 \\
\hline Kecioren & 0.1139 & 0.2152 & -0.3410 & -0.2370 & -0.0090 & 0.1680 & 1977: 1-1996:4 \\
\hline Return on ISE & 0.1567 & 0.3041 & 0.1320 & 0.0190 & -0.0950 & -0.2320 & 1986: 1-1996:4 \\
\hline Inflation & 0.1152 & 0.0566 & 0.2810 & 0.1380 & 0.1170 & 0.2010 & 1977: 1-1996:4 \\
\hline
\end{tabular}

of apartment with 100 square metre area based on 1996 prices.

In addition to the returns on real estates located in 13 different neighbourhoods in Ankara, ${ }^{5}$ the models are also estimated for the return on the ISE index. Table 3 presents some descriptive statistics of the quarterly returns and inflation for the period analysed.

\section{RESULTS}

\section{Hedging behaviour of residential real estate}

Table 4 presents the results of the test of inflation hedging behaviour of the return on residential real estate in thirteen neighbourhoods in the city of Ankara and the return on the ISE stock index using the Fama-Schwert model with three different inflation expectations. In order to eliminate any changes in the size of the apartments over the time period covered between 1977 and 1996, the returns on residential real estate are calculated using the changes in the median value of apartments converted into 100 square metre space. Since the last two measures of the expected inflation are available after 1985, the last two tests examine the FamaSchwert model only for that period. ${ }^{6}$

The results suggest that residential real estate investment in several neighbourhoods in Ankara does not behave as hedges for expected and unexpected inflation. Most of the coefficients on expected and unexpected inflation are found to be not significantly different from zero. The coefficients and their significance are different depending on the proxy used to measure expected inflation. In only two neighbourhoods, Ayranci and Kavaklidere, the coefficient on the expected inflation is found to be significantly positive when the third proxy is used to measure expected inflation. Relatively moderate- and high-income households are considered to be living in both of these neighbourhoods. Most of the coefficients on the unexpected inflation are found to be negative but significant in only five neighbourhoods. In Demetevler, Etlik and Aydinlikevler where relatively lowand moderate-income households live, the coefficient is significantly less than zero. We cannot make any generalization regarding income level, because this coefficient is found to be negative and significant in G.O.P. where the average median apartment value is highest. Unlike the previous studies, we could not observe a hedging characteristic of residential real estates under high inflation in Ankara. The coefficient on unexpected inflation is found to be significant and positive in only Dikmen which has been open for urbanization within the last 15 years and still in this process of urban development.

The hypothesis of the equality of the coefficients on expected inflation in all neighbourhoods and the equality of coefficients on unexpected inflation is tested with $F$-test. The results suggest that these coefficients are not equal in all neighbourhoods using the first and third proxies for expected inflation. However, this hypothesis failed to be rejected when the lagged return on T-bill is used as a measure of expected inflation.

The hedging behaviour of the ISE stocks seems to be similar to the hedging behaviour of the stocks in other countries. Unlike the US market, ISE stocks do not act

\footnotetext{
${ }^{6}$ In comparing the results with different inflation measures, the first proxy is also calculated for the period between 1986 and 1996. The results were similar to those obtained for the whole period with only slight differences.

${ }^{7}$ These models are also tested for the median apartment values instead of the median value for apartments with 100 square metres, the results were similar to those reported here.
} 


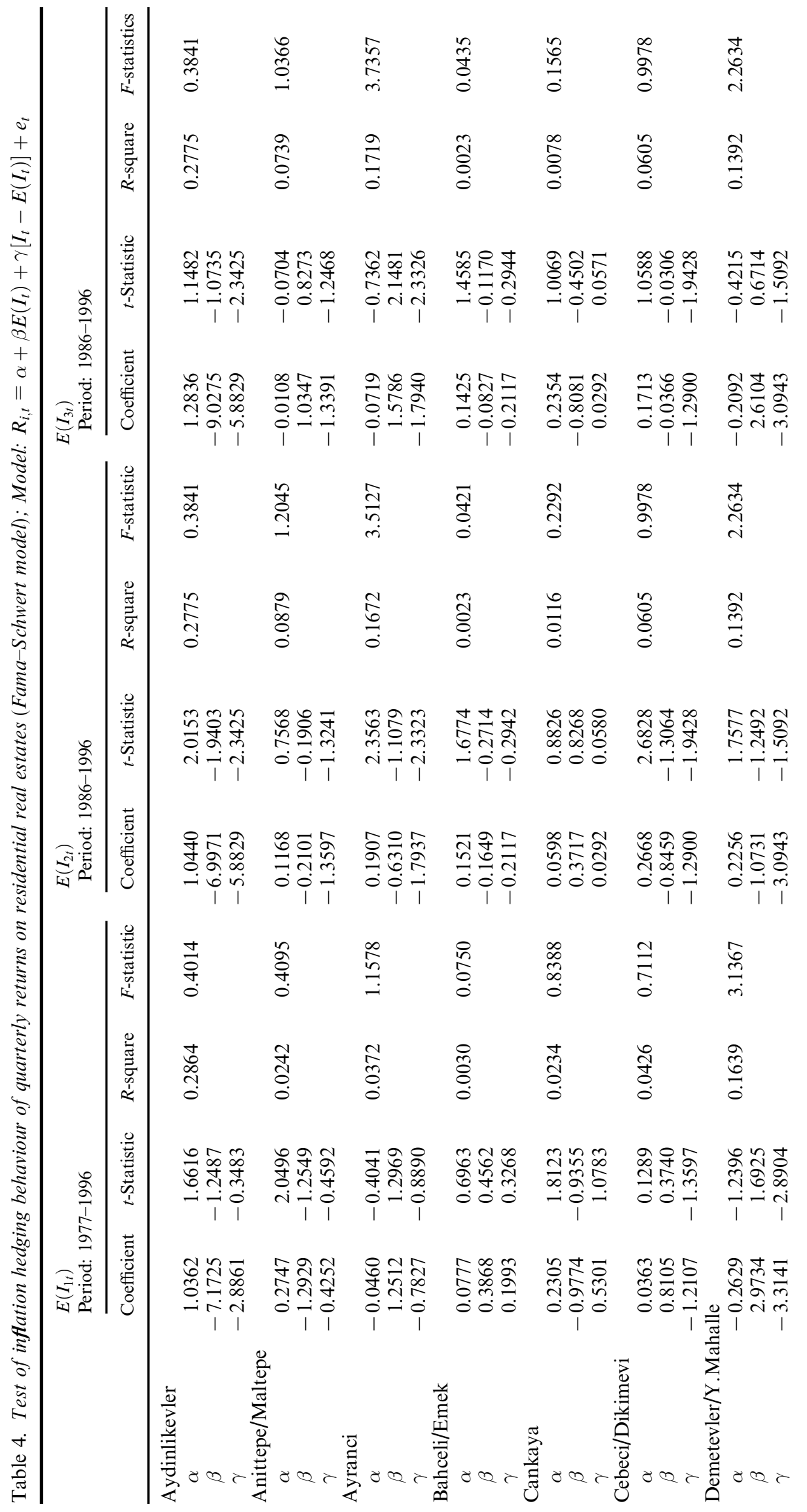




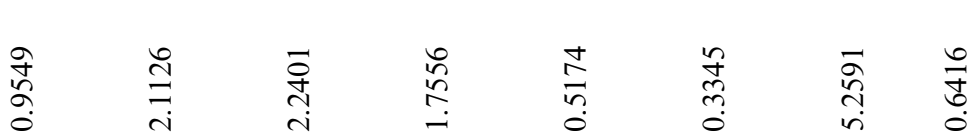

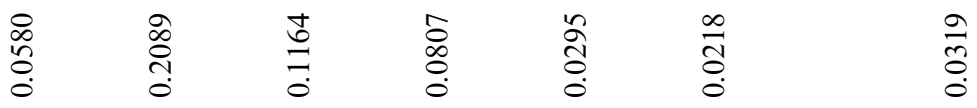

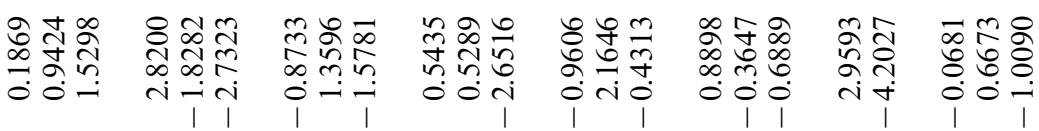

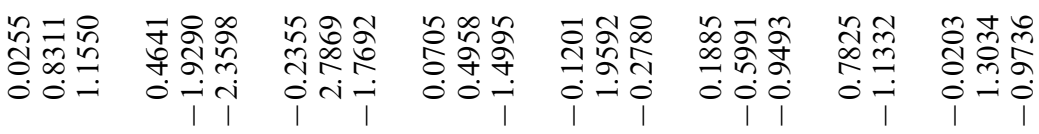

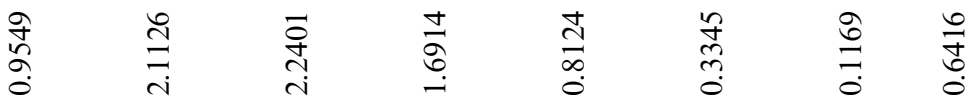

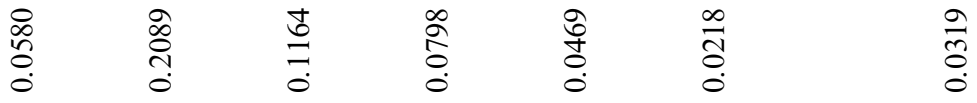

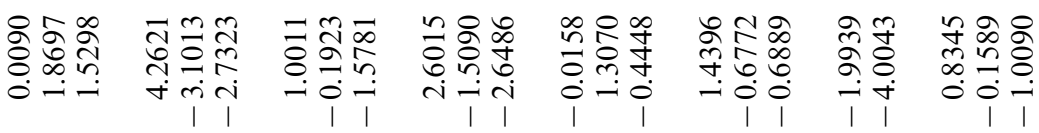

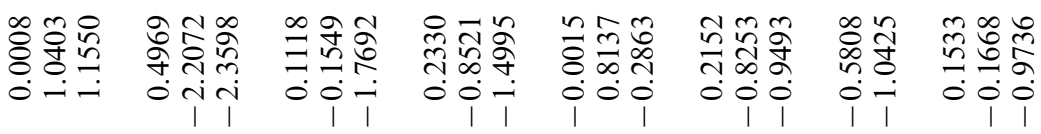

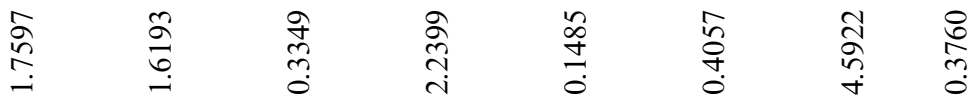

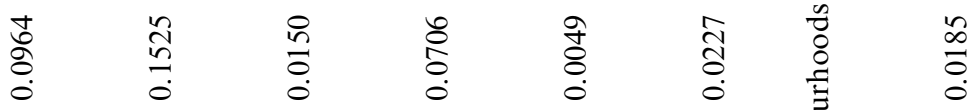

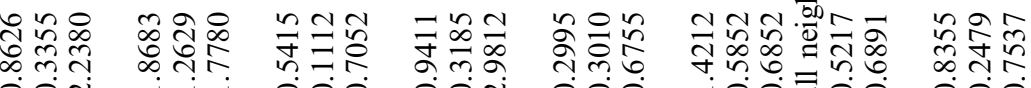
0ंग

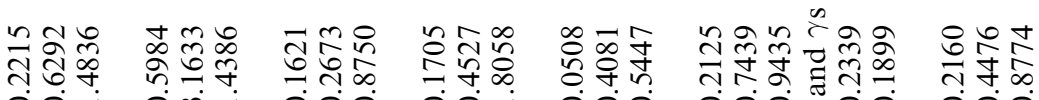

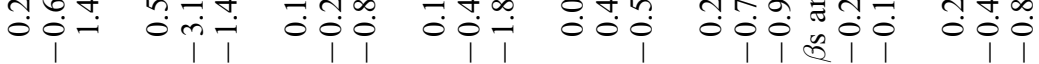

苛 


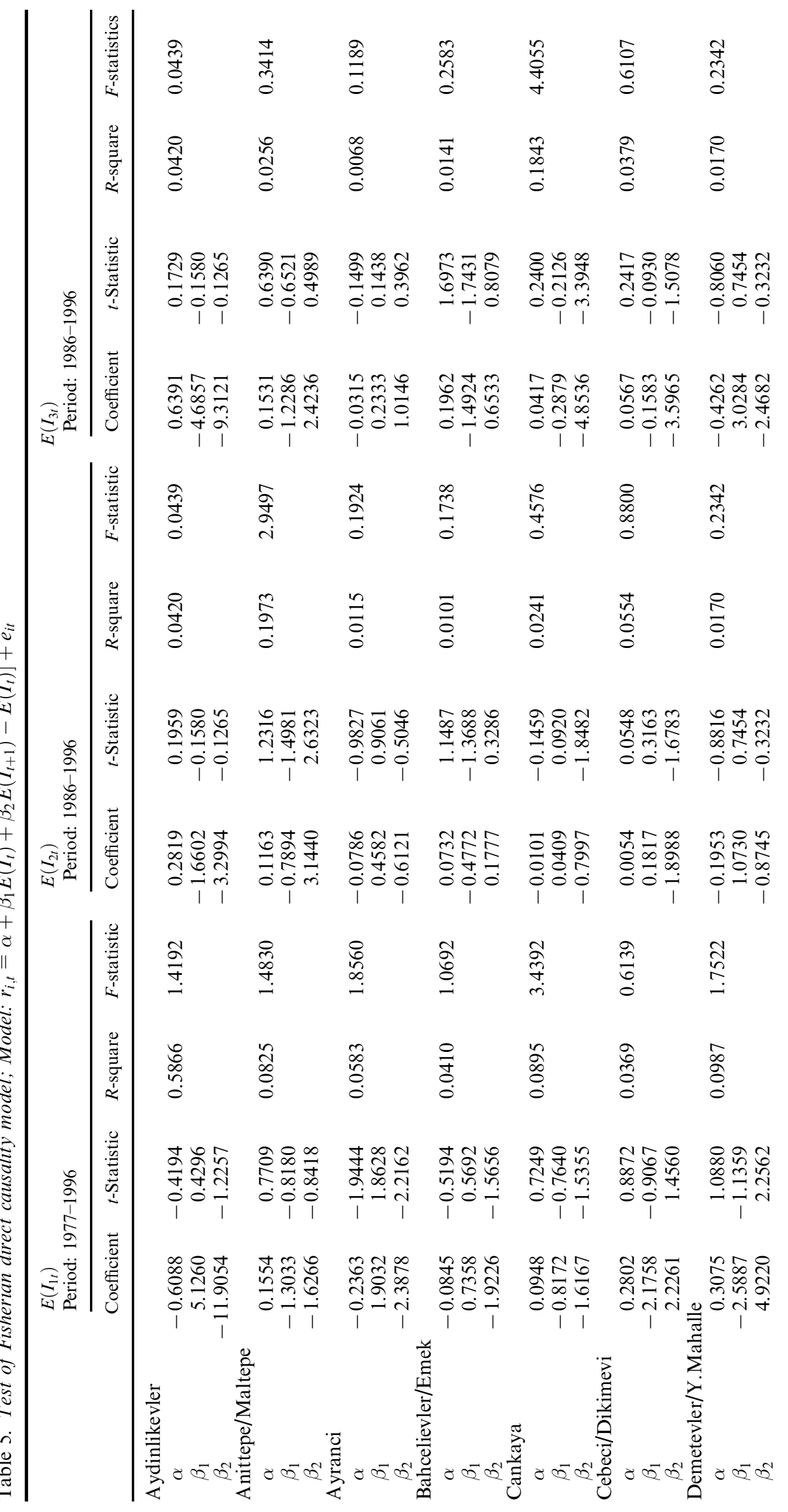




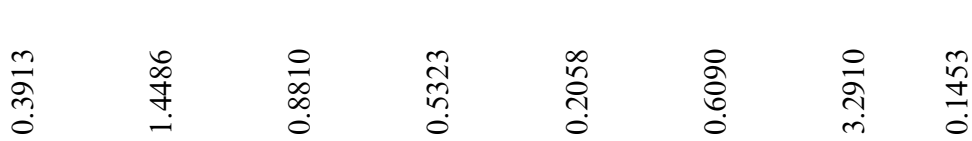

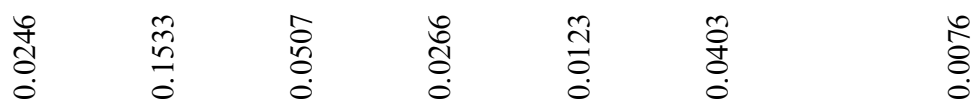

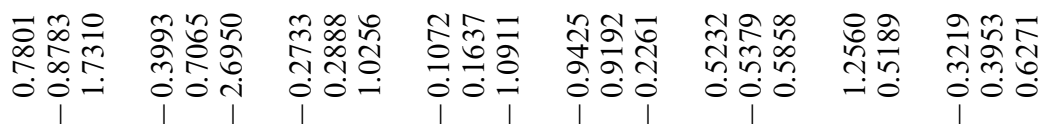

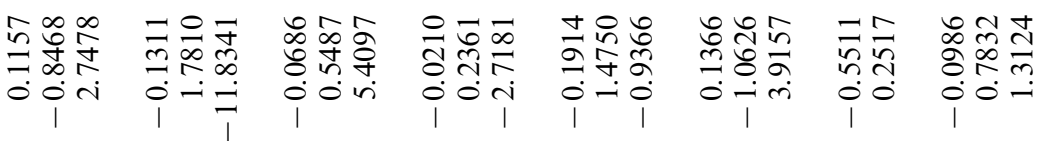

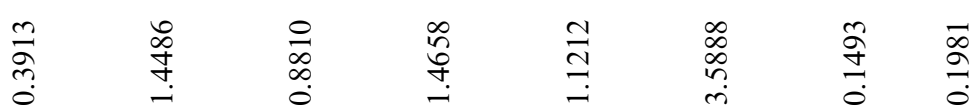

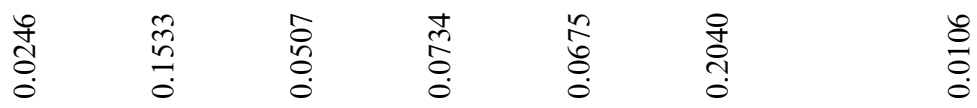

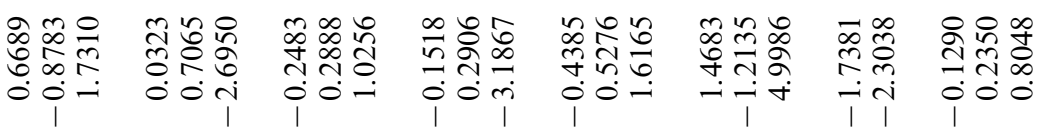

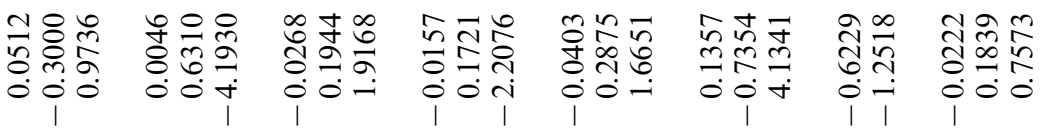

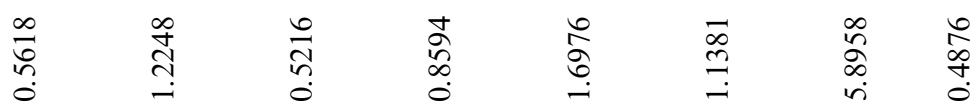

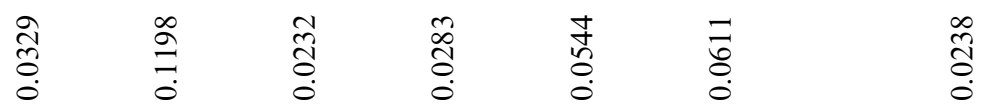

0i

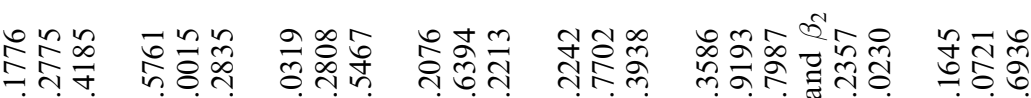

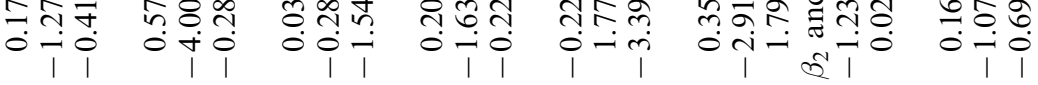

泀 


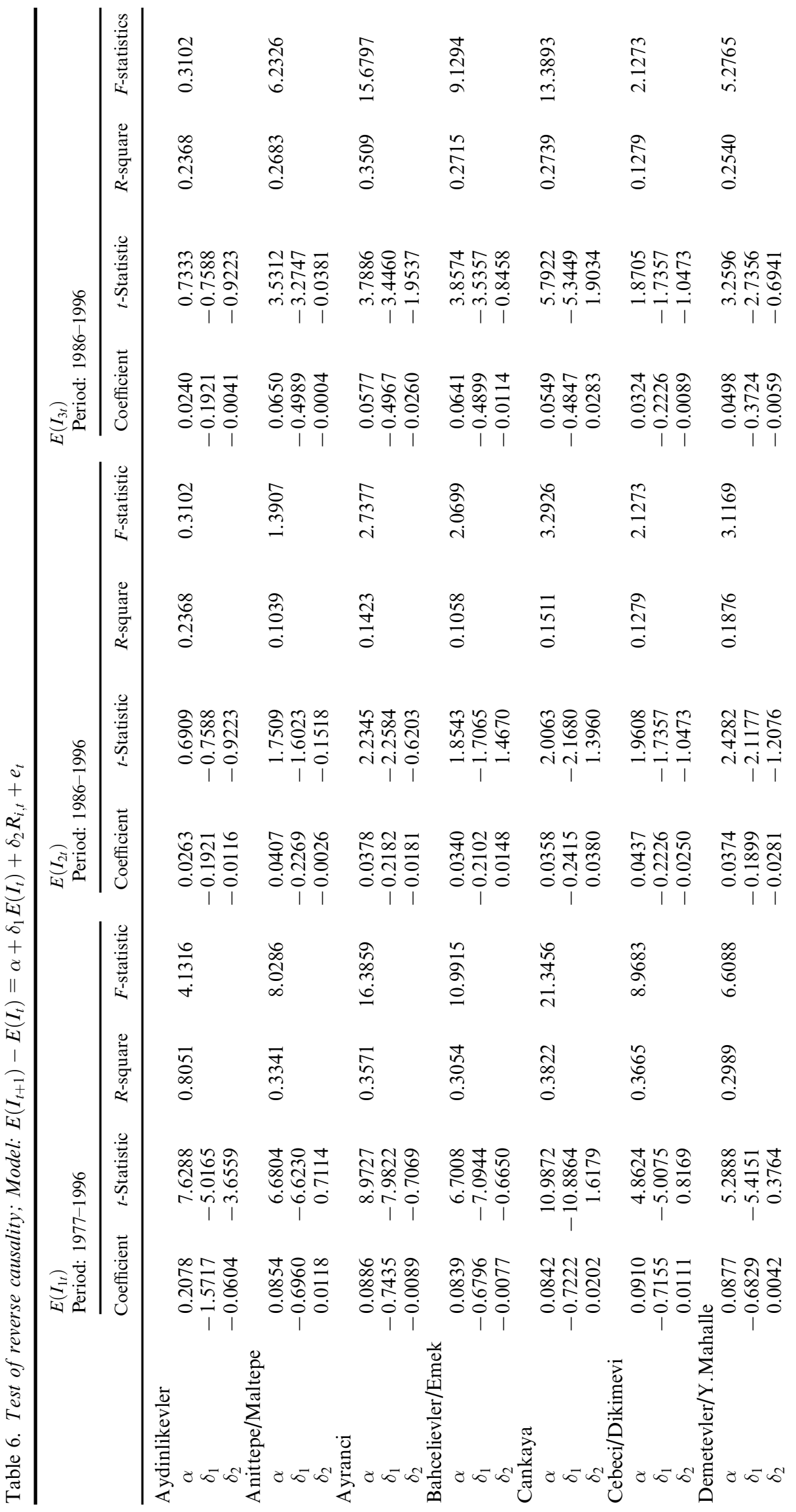




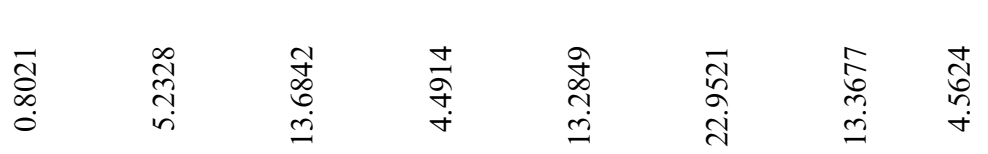

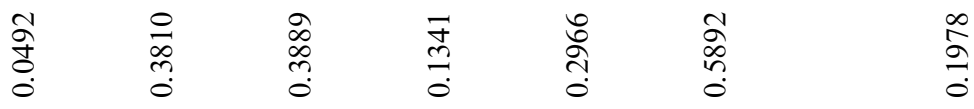

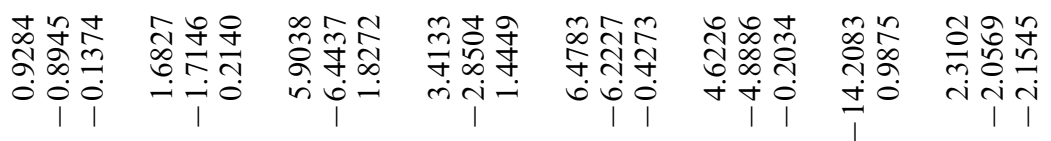

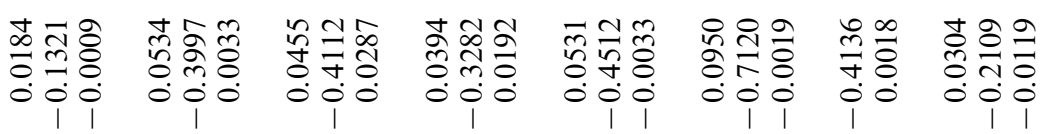

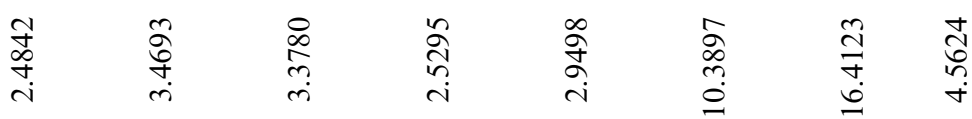

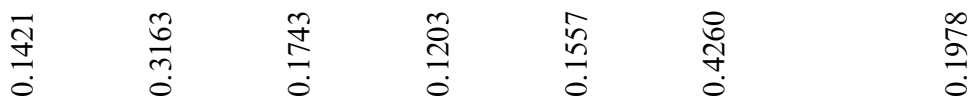

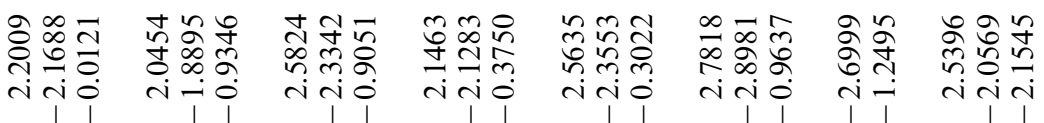

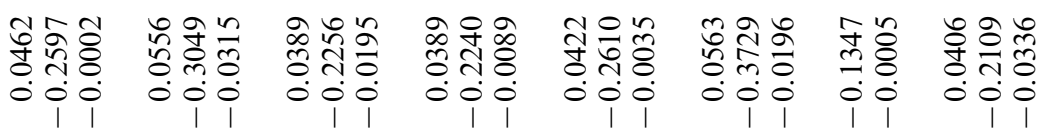

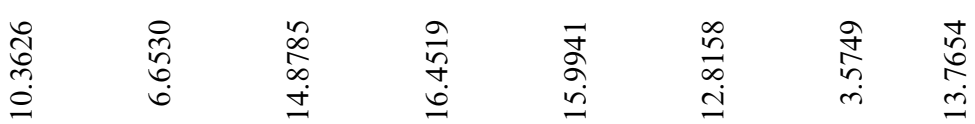

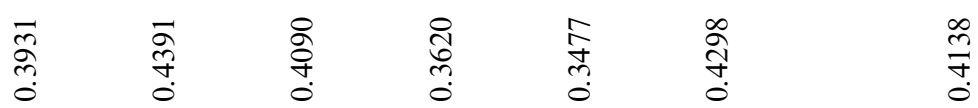

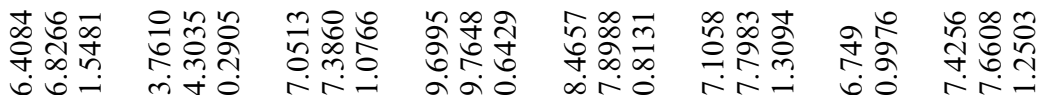

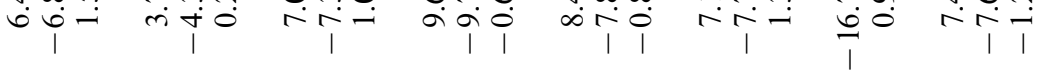

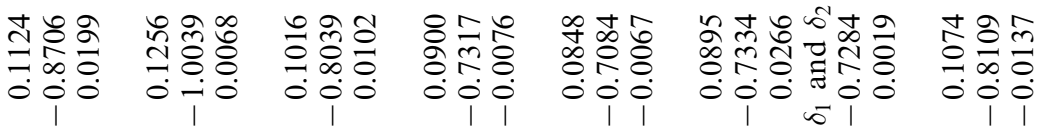

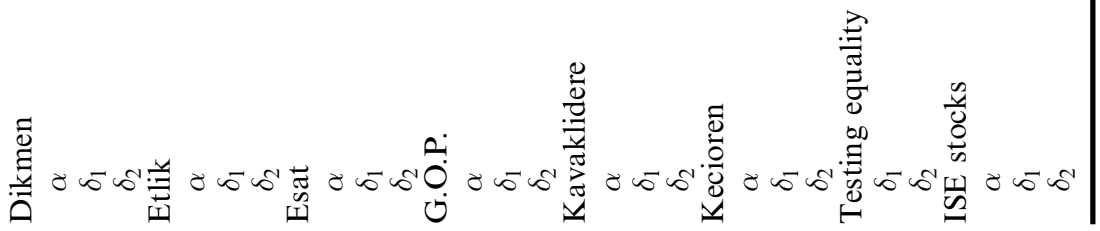


in a perverse manner in hedging expected inflation. The coefficients are not significantly different from zero even though almost all coefficients are found to be negative regardless of the measure of expected inflation.

Table 5 presents the estimations for the hypothesis that real returns are affected only from real factors but not inflation expectations. Even though the signs seem to be similar among three measures, the significance of coefficients seems to depend on the measure of expected inflation. Most of the coefficients are found to be not significantly different from zero, as the null hypothesis suggests. However, the results are slightly different depending on the measure of expected inflation. In all of the neighbourhoods, the expected inflation and the appreciation in house values are found to be not significantly related, except in Kecioren. In the relatively high income level neighbourhoods (Ayranci, Cankaya and G.O.P.), there is a negative relationship between changes in expected inflation and the real return on residential real estate. On the other hand, in low-income neighbourhoods, there is a positive association between real returns on apartments and changes in inflationary expectations. One explanation is that when the inflation is expected to increase, high-income households prefer to make investment not in real estate but in other instruments. However, for low-income households, the cost of renting will increase as the inflationary expectations increase, as a result, the demand for owner occupancy housing will increase in the low-income neighbourhoods. The hypothesis that the coefficients are equal in all neighbourhoods is rejected when the expected inflation rate is estimated with ARMA and Fama-Gibbons models.

\section{Test of reverse causality}

Geske and Roll (1983) argue that the return on assets is not caused by the changes in inflation but changes in asset prices lead to changes in inflation expectations. Table 6 presents the results of this test. If Geske-Roll hypothesis holds, the coefficients on return on real estate and on inflation are expected to be negative. In the Turkish market, the speed of the adjustment coefficient $\left(\delta_{1}\right)$ is found to be significantly negative in almost all neighbourhoods, regardless of the proxy for expected inflation. This is also true for the ISE stocks. This result suggests that investors revise their expectations for the change in inflation using larger fraction of expected inflation. This result is consistent with the findings about Turkish inflation that it can be predicted by examining only past period inflation rates (Alper and Ucer, 1998).

When the coefficients on nominal returns on residential real estate investment are observed, the results do not support Geske-Roll argument. Almost all coefficients are found to be not significantly different from zero. So, as the return on real estate changes, we do not observe any significant change in expected inflation. However, ISE stocks behave as suggested by Geske and Roll (1983). As the return on ISE stocks increases (decreases), there is a significant decrease (increase) in the inflationary expectations.

\section{CONCLUSIONS}

This study examined the hedging behaviour of real estates against expected and unexpected inflation under high inflationary environment using three different proxies for expected inflation. The returns on real estate investments in 13 neighbourhoods in Ankara are analysed. The results suggest that unlike the behaviour of real estates in other countries, real estate investment in Ankara does not provide hedge against inflation. We do not observe a reverse causality between returns on real estate and changes in expected inflation. However, a relationship between real returns and changes in inflationary expectations seem to be different in relatively low and relatively high income neighbourhoods.

The insignificant results for the hedging behaviour of real estate in Ankara can be explained with the lenders' behaviour under high inflationary environment. Lenders adjust the interest rate on loans periodically under inflationary environment. Hence, the relative cost of owner-occupied housing will not be lower or investing in owner-occupied housing will not be inflation neutral. As a result, we do not observe an increase in demand for housing. Hence, positive relationship between returns on real estate and both expected and unexpected inflation will not be observed. Similarly, if households think money market instruments as alternatives to real estate investment, as inflation increases, the demand for owneroccupant housing will decline when the government tries to keep the positive real interest rate.

This study has some limitations. First, the data used in calculating returns on real estate are based on the characteristics of apartments on sale at the end of each quarter. Since different apartments are for sale in different periods, their characteristics will change, resulting in high variability in the returns on real estate. Second, apartments with reported value and size figures are included in the sample. Consequently, it can be argued that it does not fully represent the median value of all apartments on the market for sale at that time.

\section{R EFER ENCES}

Alper, C. E. and Ucer, M. (1998) Some observations on Turkish inflation: a random walk down the past decade, Bogazici University, Department of Economics, working paper.

Baharoglu, D., Hannah, L. M. and Malpezzi, S. (1997) Getting housing incentives right in Turkey, paper presented in the 1997 European Real Estate Meetings. 
Bodie, Z. (1976) Common Stocks as a hedge against inflation, The Journal of Finance, 31(2), 459-70.

Fama, E. F. and Gibbons, M. R. (1982) Inflation, real returns and capital investment, Journal of Monetary Economics, 9, 297323.

Fama, E. F. and Schwert, G. W. (1977) Asset returns and inflation, Journal of Financial Economics, 5, 115-46.

Federal National Mortgage Association (FNMA) (1992) Creating a Market Oriented Housing Finance System in Turkiye, Report prepared for the Housing Development Administration of Turkey.

Firth, M. (1979) The relationship between stock returns and rates of inflation, The Journal of Finance, 34(3), 743-9.

Gartzlaff, D. H. (1994) Excess returns, inflation and efficiency of the housing market, Journal of American Real Estate and Urban Economics Association, 22(4), 553-81.

Geske, R. and Roll, R. (1983) The fiscal and monetary linkage between stock returns and inflation, The Journal of Finance, 38(1), 1-33.

Goodwin, T. H. (1986) Inflation, risk, taxes and the demand for owner-occupied housing, Review of Economics and Statistics, 68(2), 197-206.

Gultekin, N. B. (1983) Stock market returns and inflation: evidence from other countries, The Journal of Finance, 38(1), 49-65.

Gyorko, J. P. L. (1988) Owner-occupied homes, incomeproducing properties, and REITs as inflation hedges: empiri- cal findings, The Journal of Real Estate Finance and Economics, 1, 347-72.

Korum, U. (1982) 1980 ve 1981 yillarinda Konut Piyasasi, Konut 81, Kent-Koop Yayinlari, No. 20, Ankara.

Liu, C. H., Hartzell, D. J. and Hoesli, M. E. (1997) International evidence on real estate securities as an inflation hedge, Real Estate Economics, 25(2), 193-221.

Manchester, J. (1987) Inflation and housing demand: a new perspective, Journal of Urban Economics, 21, 105-25.

Nelson, C. R. (1976) Inflation and rates of return on common stocks, The Journal of Finance, 31(2), 471-83.

Özmen, E. (1998) Is currency seigniorage exogenous for inflation tax in Turkey? Applied Economics, 30, 545-52.

Park, J., Mullineaux, D. J. and Chew, I. K. (1990) Are REITs inflation hedges? The Journal of Real Estate Finance and Economics, 3, 91-103.

Poterba, J. M. (1984) Tax subsidies to owner-occupied housing: an asset-market approach, The Quarterly Journal of Economics, 99(4), 729-52.

Solnik, B. (1983) The relation between stock prices and inflationary expectations: the international evidence, The Journal of Finance, 38(1), 35-48.

Summers, L. H. (1981) Inflation, the stock market, and owneroccupied housing, American Economic Review, 71(2), 429-34.

Turel, A. (1981) Ankara'da Konut Fiyatlarinin Mekansal Farklilasmasi, ODTU Mimarlik Fakultesi Dergisi, 7(1), 97109. 